\title{
Organizing Professional and Pedagogical Training to Improve English Teachers' Skills: A Literature Review
}

\author{
Urip Sulistiyo \\ Lecturer of Universitas Jambi, Indonesia \\ urip.sulistijo@,unja.ac.id \\ Septu Haswindy \\ Researcher at the Research and Development Agency of Jambi Province, Indonesia \\ d34r.w3ndy@gmail.com
}

\begin{abstract}
This literature review study aims to address the current issues on English Teachers' problems in their efforts to develop their professional and pedagogical competence, in Jambi Province, Indonesia. The critical review of relevant studies on the field of professional and pedagogical competence of EFL teachers reveals that there are several topics related to the competences and skills that teachers should have to better improve their teaching practice. In this review, the researchers present what literatures suggested and recommended in the area of teachers' professional and pedagogical competence and possible training that stakeholders might hold to improve the quality of teachers teaching English both in junior and senior high schools in Indonesia. The relevant articles being reviewed were from Indonesian context as well as International context. This study hopefully can contribute to the betterment of teaching practice of English in Indonesian schools. The following topics are presented in order; teacher's professional competence, teachers' pedagogical competence. The domains and dimensions of English teachers' competence, teachers' training, and conclusion and suggestions.
\end{abstract}

Keywords: English teachers, professional and pedagogical competence, teachers' training

Manuscript submitted: August 1, 2018

Manuscript revised: September 14, 2018

Accepted for publication: September 25, 2018

\section{Introduction}

English is either a local content or a compulsory subject in Indonesian education. It is formally introduced into primary schools as a local content subject from Year 4 and continues to Year 6. In secondary schools, English is one of the subjects examined during the Final National Examination. At university level, English is a requirement for all faculties and undergraduate majors (Yulia, 2013). Although English is globally known as an international language, in Indonesia, English is considered predominantly a foreign language, where it is commonly taught in schools alongside other subjects, such as mathematics, biology, and physics (Sulistiyo, 2008). It is not widely used as a language of instruction in education, nor in activities such as business or governance (Philipson, 1992). Therefore, in the classroom, English teachers in Indonesia must support students who have varied forms of language exposure in order to provide adequate input for English development. 
A number of studies about EFL in Indonesia suggests that the quality of English teachers who work with students in schools must be improved because they play the most important role in achieving the goals of English teaching and learning mandated by the Indonesian government (Sulistiyo, 2015). One of the most direct ways to improve the quality of English teachers in Indonesia is to improve the quality of the teacher education programs that are responsible for preparing student teachers with adequate English proficiency and teaching skills. In addition to that, providing effective teacher trainings enable English teachers to improve their teaching skills.

In order to find out what kind of teacher trainings that best meet English teachers to improve their pedagogical and professional competence, this critical literature review study presents and examines a number of relevant topics that would be fruitful information for English teachers, policymakers, and other parties in their efforts to better understand theoretical and practical issues of English teaching in Indonesian schools.

\section{Teachers' professional and pedagogical competence}

This section presents a review of studies conducted by Indonesian researchers regarding a number of aspects related to the competence of EFL teachers in Indonesia. The studies examined are from several educational institutions across Indonesia in order to enable a comprehensive overview of EFL teacher quality from local perspectives to indicate the significance of conducting research on teachers' professional and pedagogical competence. There are two themes highlighted in this section: (i) EFL teachers' competence and (ii) the domains of competence that English teachers in Indonesia must know and be able to use.

EFL teachers' competence is very important (Cahyono, 2014; Soepriyatna, 2012) in terms of the language input for students during their classroom learning (Berns, 1990; Suryati, 2012). However, a study conducted by Lengkenawati (2005) found that most Indonesian teachers lacked competence in some of the English skills they teach. For example, while a teacher may be competent using English grammar, he or she may not be proficient in English listening and reading skills. Analysis from writing tests indicated that the teachers had low knowledge of the organisation of ideas, poor use of grammar, and a very limited range of vocabulary.

Another study investigating EFL student teachers' competence was conducted by Wiyati (2014). This descriptive study involved six EFL pre-service teachers in their final year of studying English at a higher learning institution in West Java, Indonesia. Data were collected using questionnaires, classroom observations, and interviews. This study revealed that the student teachers had inadequate knowledge of teaching techniques and strategies. In terms of language proficiency, they were not proficient in using English as a subject to teach to students. Further, the student teachers showed very little comprehension of how learner evaluations should be conducted. These EFL pre-service teachers lacked the PCK important both for them as teachers and for their students during the teaching and learning process. They had low competence in using the necessary teaching strategies to cater to the students' needs and lacked important characteristics that are needed to engender interest and enthusiasm in students and to perform the various responsibilities of their professional work.

\section{Literature Review}

\section{Domains of English teacher's competence in Indonesia}

In an effort to identify and document EFL teachers' competence, Soepriyatna (2012) conducted a study to explore and describe the domains of EFL teachers' competence in Indonesia. In doing so, Soepriyatna reported on the competencies required by school teachers of English in Indonesia and described the development of performance tasks used to assess this. Theories of teacher competence proposed by Cross (2003), Mulhauser (1958) and Richards 
(1998) were used as a framework to underpin this study. The framework of teacher competence comprised three domains: language competence, content knowledge about language, and teaching skills. A survey was used to elicit what the study respondents believed high school teachers of English in Indonesia should know and be able to do. The participants were high school teachers of English, principals, faculty members, teacher educators, supervisors and scholars with an English language teaching (ELT) background. In addition, a performance task was developed to assess the competence dimensions of the teachers.

From this study, Soepriyatna (2012) generated the domains and dimensions of competence required for high school teachers of English in Indonesia. In the English language competence domain, this study claimed that English teachers must have oral and written communication abilities and linguistic and socio-cultural knowledge. In the teachers' content knowledge domain, they must have text types and grammar point knowledge. In the teaching skills domain, they must know about lesson planning, which encompasses the objectives and material development of the lessons taught. In addition, they must perform their teaching effectively by demonstrating knowledge of learning management, teaching techniques, learning styles, learning strategies and other qualities of engaging teachers. The following matrix of the competence of high school teachers of English in Indonesia was adapted from Soepriyatna (2012).

Table 1. The domains of English teacher competence

Domains/Characteristics Operational Definitions

English Language Competence Domain

Oral/written communication

Can understand the main ideas of a discourse, interact with students fluently, and produce clear discourse to present and explain lesson content

Linguistic

Can use vocabulary correctly and appropriately, maintain grammatical accuracy, pronounce words and sentences correctly and naturally, and write accurately

Can express ideas politely in formal or informal

Sociocultural expression appropriate to the situation and participants involved

Content Knowledge Domain

Text types

Can inform in a spoken and written text based on the conventions in a particular context

Grammar points

Can show mastery of grammar points being taught

Teaching Skill Domain: Lesson Planning

Objectives

Can formulate statements of intended learning outcomes

Can produce learning and teaching materials that

Material development integrate learning objectives, engaging learning tasks, and assessment related to materials

Teaching Skill Domain: Teaching Performance 
Domains/Characteristics

Learning management

Teaching techniques

Learning styles

Learning strategies

Qualities of engaging teachers
Operational Definitions

Can organise pair, group, and class work; give classroom commands; time a lesson; and maintain attention

Can apply teaching techniques that promote students' engagement

Can stimulate students to use multiple modes of information processing

Can demonstrate to students how to learn

Can perform verbal and nonverbal expression to encourage students to participate in learning activities

A teacher's ability to speak English well will benefit students in an EFL teaching context in two ways. When this occurs, English is used as the classroom medium of instruction, and students are exposed to their teachers as English language role models. English competence must distinguish English teachers from other teachers. It is critical that student exposure to English language role models occurs, as a defining feature of the EFL classroom. Soepriyatna (2012) suggested that competent teachers must have language content knowledge. Content knowledge enables teachers to help students cope with problems encountered while learning and understanding the topics covered in lessons. Content knowledge includes aspects such as grammar and the other features of language mastery that are necessary for students to build communicative competence in their use of English. Soepriyatna also stated that English teachers require another kind of knowledge-one that enables them to transfer content knowledge to students effectively. In teaching generally, this includes knowledge of techniques relevant to the content involved, which is what Shulman (1986) termed PCK. The findings from Soepriyatna's (2012) study support Shulman's (1986) statement that an effective teacher has both subject content knowledge and the ability to transfer this knowledge to students through considered use of appropriate teaching techniques, adjusted to the contextual aspects of their class. For EFL teaching in Indonesia, this knowledge must be developed to align with typical Indonesian classrooms - a context where large numbers of students are in the classroom.

Another conclusion to be drawn is that motivation is an important factor in student engagement, and teachers must develop abilities and skills to stimulate interest in their students. For example, during lesson preparation, teachers must foster student engagement with carefully designed and clearly stated communicative competence intentions. One way of doing this is by outlining standards that students must meet, and the procedures for assessing performance that will demonstrate these standards. In addition, teachers must be able to create an atmosphere in their classroom that is conducive to student learning. In order to achieve this, competent teachers use a variety of techniques to accommodate and facilitate various learning styles.

\section{Discussion}

\section{Teachers' training program}

To improve and maintain quality with EFL teacher competence in Indonesia, programs such as lesson study and teacher professional development could be useful for teachers to undertake. Lesson study is considered an effective approach to professional development and school improvement in Indonesia (Suratno, 2012). According to Perry and Lewis (2009), lesson 
study is a cycle of instructional improvement that involves teachers in active learning about the teaching content. It is an intensive, collaborative and practice-based activity that strengthens the professional community and improves the use of teaching and learning resources. In the lesson study program, teachers observe each other's classroom practices and work together to refine individual lessons in order to build strong connections between teachers' learning about content and students' learning outcomes (Suratno, 2012).

In relation to EFL teachers' professional competence, Cahyono (2014) conducted research examining the implementation of lesson study in Indonesia. The lesson study in Cahyono's investigation sought to improve EFL teachers' pedagogical content competencies in teaching and learning with senior high schools in Southern East Java. It focused on how EFL teacher training and EFL supervision programs could be implemented to improve pedagogical content competencies. In this manner, the lesson study served as a supportive vehicle for teacher learning. The findings showed that lesson study was useful in helping teachers develop their PCK. Moreover, the participants of the study argued that teacher training and EFL supervision helped them better understand how to apply PCK to design and implement instructional materials. Cahyono's (2014) study suggested that language teachers should and can improve their pedagogical content competence continuously in order to help students meet curriculum requirements. It emphasised the importance of lesson study as a platform for sustaining teachers' learning in order to develop and improve pedagogical content competence. The implication to be drawn from the study findings is that teacher professional development and teacher learning activities must affect teacher quality and student learning.

Programs for teacher professional development-such as lesson study-are considered essential to improving teachers' competence. According to Richards and Farrel (2005), from an individual teacher's perspective, improving teaching skills to develop confidence regarding the teaching material will lead to better results for students. They stated that areas for teacher professional development include subject matter knowledge, pedagogical expertise, selfawareness, understanding of learners, understanding of the curriculum and materials, and plans for career advancement. The scope and implementation of teacher professional development in Indonesia has been investigated by several scholars. For example, Irmawati (2014) proposed that models of EFL teacher professional development must be linked to visions for EFL teacher professionalism in an Indonesian context.

While 'teacher professional development' is a term used to describe the continuing process of teacher improvement, in the context of EFL teachers, the term is specifically used to refer to the process in which teachers increase their English skills and propositional and procedural EFL knowledge sets. As explained earlier, the position and use of English by teachers in the EFL classroom is the essential source of expertise and knowledge for students to learn and practice the target language. Thus, the role of the teacher in contributing to students' success in learning the target language in this EFL context is crucial (Irmawati, 2014; Mbato, 2013; Sulistiyo, 2009; Yuwono, 2005).In response to this essential role of EFL teachers, models of teacher professional development proposed by Irmawati (2014) must cover two areas:

- propositional knowledge-encompassing the content subject that teachers teach, such as the English materials they use

- procedural knowledge-related to the processes, procedures, and strategies that help teachers perform teaching tasks.

One specific model of teacher professional development includes implementing a 'critical friends group', which involves teachers as researchers working with material development activities, where experts are invited into school contexts to join these training and development programs (Irmawati, 2014). All these proposed models seek to help teachers build English competence and English-teaching skills. They also aim to create a change in mindset in relation to strengthening teachers' identity as English teachers by implementing these models of 
professional development. Irmawati (2014) also stated that models that involve colleagues giving feedback and suggestions to each other benefit teachers in many ways. First, teachers gain more objective feedback to enable reflection on their teaching practice, and this objective feedback broadens the ways they can think about how to teach more successfully. Second, teachers can share ideas related to applicable techniques to use more effective and interesting materials during their teaching practice. Having teachers conduct research-particularly action research-is useful because it enables them to identify problems that occur in their own classroom contexts. They are able to build skills and knowledge regarding ways to solve their students' problems during the learning process. Additional benefits to those from implementing actions following reflection include improved writing skills gained from reporting their research in written form.

Another study that investigated teachers' professional development occurred in South Kalimantan, Indonesia, conducted by Rahayu (2014). This was undertaken in Hulu Sungai Selatan district with 35 English teachers from several Islamic secondary schools, who completed a questionnaire and took part in an in-depth interview. This study investigated three categories of teacher professional development:(i) ongoing development, (ii) development through reading and further study and (iii) further skill development. First, in terms of ongoing development, the English teachers completed activities to enhance their professional expertise through personal reflection and collaborative discussion with colleagues. During this collaborative discussion, they undertook informal conversations with their colleagues to share problems and discuss possible solutions to these problems. Most teachers described the benefits as feeling more comfortable in finding a solution to problems and exploring new teaching ideas. Other ongoing development activities - such as peer observation and collecting student feedback-were not undertaken. This was because peer observation was not school policy and they felt uncomfortable with its potential for criticism.

Second, in undertaking teacher development through reading and further study, there were many difficulties to overcome. The participants revealed that, while they read materials related to English teaching, there were limited reference books available. Moreover, internet access was limited and other activities - such as continuing further study and joining a workshop-were difficult to complete due to funding and time problems. Third, further development of teachers' professionalism activities — such as joining a professional association, sharing techniques and methods, writing in academic journals, undertaking action research, and conducting comparative studies-was not undertaken, except for teachers joining professional associations. However, they did not attend meetings regularly because they were busy with their teaching rosters.

Teacher professional development can also be done by establishing an English teacher working group, or 'Musyawarah Guru Mata Pelajaran'. In investigating the roles of English teacher working groups to support teacher professional development in Pontianak municipality, Barella (2014) found that this teacher association has contributed greatly to the development of junior high school English teacher professionalism in developing the syllabus, annual and semester programs, lesson plans, teaching methods, innovative learning modes, use of teaching media and evaluation systems. In addition, it improved general teacher competence. Thus, these activities undertaken by the association contributed greatly to increasing the ability of English teachers to perform their teaching tasks.

\section{Conclusion and Suggestions}

In summary, in EFL teaching and learning contexts, teacher competence is essential to facilitating successful English exposure and learning during classroom activities. A number of Indonesian scholars are aware of this importance-for example, Soepriyatna (2012) identified the domains of EFL teachers' competence in Indonesia. These domains can inform teacher education programs to design the curriculum in ways that align with the needs of EFL teachers 
during their classroom preparation. There is a need to provide EFL teachers with training to improve their teaching and performance in other roles when working with students in. This can be most directly addressed by carrying out in-service training to expand and update their teaching approaches and understanding of what is most appropriate for preparing students with successful learning.

This review study has revealed that, among other things, English teachers need to become better role models for student teachers through the effective demonstration and modelling of concepts and the practical aspects of learning and teaching. In-service training can address several identified aspects of what teachers need to know and be able to do to provide 'learning' to students. This can be done by exposing them to new pedagogies for EFL teaching and to new educational theories and knowledge. Besides, in-service training, teachers can undertake other activities to enhance their professional expertise through gaining further academic qualifications. So, recommending that teachers pursue higher degrees is a good option to enhance professional development and knowledge, not only for the individuals concerned but also that which arises from the collegial impact and leadership when they return to their schools. In-house training is another approach to improving and updating teaching skills. schools can arrange workshops on new teaching approaches and methodologies. This can be done, for example, by inviting senior teachers or experts from other schools in Indonesia or even from overseas.

Maximizing English Teacher Working Group (MGMP) is another way to improve the quality of English teachers in terms of their professional and pedagogical competence. MGMP is a program that provides teachers with new updated information about teaching and learning issues. It also provides various training in relation to curriculum, Language assessment, classroom management and so on and so forth. Current practice of MGMP is not optimum due to some obstacles that this organization might have. Less support from school authority is also another factor affecting the performance of this organization. In the future, maximizing the performance of MGMP is an effective way to improve the quality of the teachers in terms of their professional and pedagogical competence.

\section{References}

Berns, M. (1990). 'Second' and 'foreign' in second language acquisition/foreign language learning: A sociolinguistic perspective. In B. Van Patten and J.F Lee (Eds.), Second language acquisition-Foreign language learning. Philadelphia, PA: Multilingual Matters Ltd.

Cahyono, B. Y. (2014). Quality of Indonesian EFL teachers: The implementation of lesson study to improve teacher pedagogical content competence. In H. Widodo \& N. Zacharias (Eds.), Recent issues in English language education (pp. 65-88). Surakarta, Indonesia: UNS Press.

Cross, D. (2003). Language teacher preparation in developing countries: Structuring pre-service teacher training program. English Teaching Forum, 41(4), 41-43.

Irmawati, D. K. (2014). Models of TEFL teachers' professional development. Paper presented at the TEFLIN International Conference, Solo, Indonesia.

Lengkenawati, N. S. (2005). EFL teachers' competence in the context of English curriculum 2004: Implication for EFL teacher education. TEFLIN Journal, 16(1), 79 - 92.

Mbato, C.L. (2013). Facilitating EFL learners' self regulation in reading: Implementing a metacognitive approach in an Indonesian higher education context. Lismore, NSW: Southern Cross University.

Mulhauser, R. (1958). Upgrading the in-service teacher. Modern Foreign Languages in the High School Bulletin, 16, 140 .

Perry, R.\& Lewis, C. (2009). What is successful adaptation of lesson study in the US? Journal of Education Change, 10(4), 365-391.

Philipson, R. (1992). Linguistic imperialism. Oxford, England: Oxford University Press. 


\section{Edukasi}

Rahayu, P. S.\& Hizriani, N. (2014). English teachers' professional development at Hulu Sungai Selatan. South Kalimantan. Paper presented at the TEFLIN International Conference, Solo, Indonesia.

Richards, J.C. (1998). Beyond training: Perspectives on language teacher education. Cambridge, England: Cambridge University Press.

Richards, J. C. \& Farrel, T.S.C. (2005). Professional development for language teachers. New York, NY: Cambridge University Press.

Shulman, L.S. (1986). Those who understand: knowledge growth in teaching. Educational Researcher, 15, 4-14.

Soepriyatna, S. (2012). Investigating and assessing competence of high school teachers of English in Indonesia. Malaysian Journal of ELT Research, 8(2), 38-49.

Sulistiyo, U. (2009). Learning English in an Indonesian university: A study of learners' preferred activities. La Trobe University.

Sulistiyo, U. (2015). Improving English as a foreign language teacher education in Indonesia: The case of Jambi University. (Doctoral dissertation ). Available from https://researchbank.rmit.edu.au/view/rmit:161521

Suryati, N. (2013). Developing an effective classroom interaction framework to promote lower secondary school students' English communicative competence in Malang, East Java, Indonesia (Unpublished dissertation). The University of Newcastle, NSW.

Yulia, Y. (2013). Teaching challenges in Indonesia: Motivating students and teachers' classroom language. Indonesia Journal of Applied Linguistics, 3(1), 1-16.

Yuwono, G. (2005). English language teaching in decentralised Indonesia: Voices from the less privileged schools. Paper presented at the AARE 2005 International Education Research Conference, The University of Sydney, Sydney, NSW.

Yuwono, G.I. (2008). Indonesian EFL teachers' professionalism: A case study in Salatiga municipality (Unpublished doctoral dissertation). University of Sydney, Sydney, NSW. 